\title{
軸流ファンにおけるモーダル波の発生点近傍での動翼先端流れ場*
}

\author{
西 岡 卓 宏*1, 菅 野 俊 男*2
}

\section{Rotor Tip Flow-Field near Inception Point of Modal Disturbance in an Axial-Flow Fan}

\author{
Takahiro NISHIOKA*3 and Toshio KANNO \\ *3 Mechanical Engineering Research Laboratory, Hitachi, Ltd., \\ 832-2 Horiguchi, Hitachinaka-shi, Ibaraki, 312-0034 Japan
}

\begin{abstract}
The rotor-tip flow fields in a low-speed axial-flow fan were experimentally and numerically investigated to clarify the mechanism behind the modal stall inception. The interface between the incoming flow and the reversed tip-leakage flow does not become parallel to the leading edge plane, although backflow from the trailing edge initiates near the stall condition. The reversed tip-leakage flow does not spill from the leading edge at the stall condition. Moreover, the tip-leakage vortex breakdown does not occur near or at the stall condition. A three-dimensional separation vortex is induced by secondary flow on the suction surface near the stall condition and develops at the stall condition. It is concluded from these results that the rotor-tip flow fields in the modal stall inception differ from those in the spike stall inception and that the three-dimensional separation vortex induced by the secondary flow influences the initiation of the modal disturbance.
\end{abstract}

Key Words : Rotating Stall, Turbomachinery, Axial-Flow Fan, Modal Disturbance

\section{1. 粕}

軸流ファンや軸流圧縮機で発生する旋回失速は，作 動限界を支配する不安定現象であり，作動範囲拡大の ためには旋回失速の発生過程の解明が重要となる.こ のため, 軸流王縮機を対象として旋回失速の発生過程 が研究されており(1),(2)，二つの発生過程が報告されて いる. 第一の発生過程はスパイク型として知られてお り(1)，小スケール失速セルが最初に現れ，このセルの 発生後に大スケール失速セルが発達する. 第二の発生 過程はモ一ダル型として知られており, 微小じょう乱 波が最初に発生し，このじょう乱波の発生後に大スケ 一ル失速セルが発達する(2).

筆者らは動翼スタッガ角に対する旋回失速の発生過 程の変化を実験的に調べ, 各動翼スタッガ角での発生 過程が異なることを確認した(3)(4). また，設計スタッ ガ角での小スケール失速セルの発生メカニズムを数值 解析から検討し(5), Voら(6)と同様, 小スケール失速セ ルの発生点近傍では動翼流入流れと翼端漏れ流れの境 界が，動翼前縁と平行になることを確認した. また，

\footnotetext{
* 原稿受付 2010 年 5 月 26 日.

*1 正員, (株) 日立製作所機械研究所(函312-0034 ひたちなか 市堀口 832-2).

*2 (株) 日立プラントテクノロジー(恶 300-0013 土浦市神立町 603).

E-mail : takahiro.nishioka.sf@hitachi.com
}

Vo ら(6) とHah ら(7)が示した, 旋回失速発生点近傍で の翼端漏れ流れの隣接翼間への流入も数值解析から確 認した. さらに, 古川ら(8),(9)と山田ら(10)が示した小ス ケール失速セルの発生点近傍での翼端漏れ渦の崩壊も 確認した.

上述のように，小スケール失速セルの発生から始ま るスパイク型の旋回失速発生メカニズムに関しては解 明されつつある. しかし，モ一ダル型の旋回失速の発 生メカニズムに関しては報告が少なく(2)(11), 動翼先端 流れ場の影響は明らかになっていない。このため, 本 研究ではモーダル型の発生メカニズムの解明を目的と して, モ一ダル波の発生点近傍での動翼先端流れ場と 翼端漏れ渦の変化を数值解析により調べた.

\section{2 おな記号}

$\begin{array}{ll}C & : \text { 動翼コード長 }(\mathrm{mm}) \\ C C F & : \text { 相互相関関数 } \\ C p & : \text { 動翼先端周速に基づく翼面圧力係数 } \\ C p^{\prime} & : \text { 動翼先端周速に基づく圧力変動係数 } \\ H & : \text { 動翼高さ (m) } \\ H n & : \text { 無次元化したヘリシティ } \\ h & : \text { 動翼ハブ面からの距離 }(\mathrm{m}) \\ T & : \text { 動翼回転周期に基づく無次元時間 } \\ X & : \text { 動翼前縁からの距離 (m) } \\ \phi & : \text { 動翼先端周速に基づく流量係数 }\end{array}$




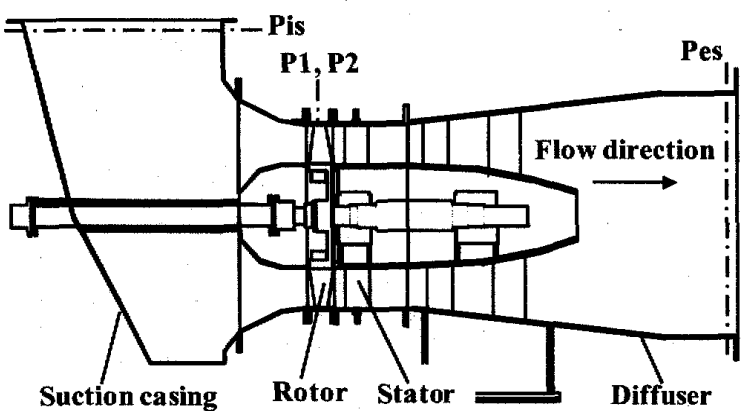

Fig. 1 Schematic diagram of fan

Table 1 Design specifications of the fan

\begin{tabular}{|l|c|}
\hline Tip diameter (mm) & 685 \\
\hline Hub/ tip ratio & 0.57 \\
\hline Rotor tip clearance (mm) & 1.5 \\
(\% of rotor tip chord) & $(2.0)$ \\
\hline
\end{tabular}

ঋ : 動翼先端周速に基づく圧力係数

添え字

a : 軸方向

t : 動翼先端

BPF : 動翼通過周波数成分

3. 供試軸流ファンと旋回失速の発生過程

3.1 供試軸流ファンと実験方法 図 1 に供試軸流 ファンの断面図を, 表 1 に仕様を示す. 軸流ファンは 動翼列と静翼列，並びに吸込みケーシングとディフュ 一ザから構成されている. 動翼先端径は 685mm であ り，八ブ比は 0.57 である. 動翼先端隙間は $1.5 \mathrm{~mm}$ で あり, 先端コード長の $20 \%$ となる、動翼列と静翼列 の仕様に関しては, 前報(3)に記載しているので参照さ れたい. 解析では実験によりモ一ダル波の発生か確認 できた, 動翼スタッガ角を設計值から $10^{\circ}$ 小さくし た状態 (以下，小スタッガ角と略す）を対象とした.

図 2 に動翼先端での翼配置を示す.

ファン性能は図 1 に示した吸込ケーシング入口(Pis) からディフューザ出口(Pes)までの全圧上昇で評価した. また，図 1 に示した動翼前縁部のケーシング上の P1 と P2 に, 半導体圧力センサ (Kulite XT-140) を設置 して死力変動を測定した. 失速セルの伝播速度を測定 するため，P2はP1 から動翼回転方向に $120^{\circ}$ 離して 設置した.さらに，図 2 に示したケーシング上の C1 から C8 の位置で圧力変動を測定し, 動翼先端での翼 負荷を推定した. 表 2 に動翼前緑と測定位置 (C1 か ら C8）までの距離を示す. 表中の距離は, 動翼先端 の軸力向コード長 $\left(\mathrm{C}_{a}\right)$ を用いて無次元化している.

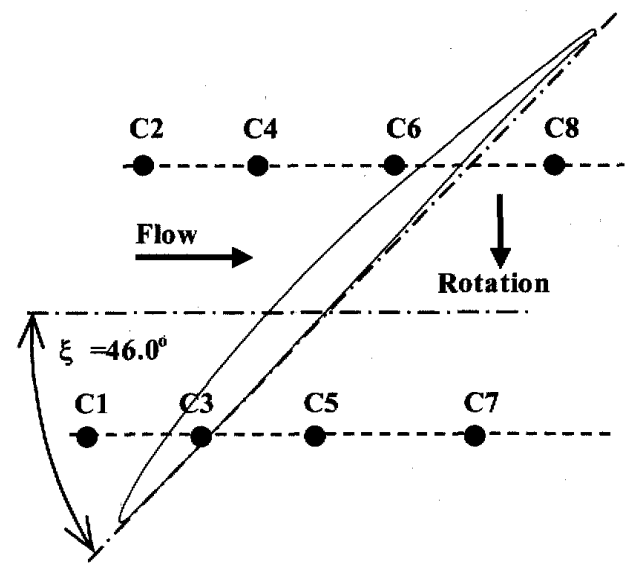

Fig. 2 Blade configurations at rotor tip

Table 2 Axial distances between leading edge and

measurement points on casing wall
\begin{tabular}{|l|l|}
\hline & $X / C_{\text {t }}$ \\
\hline C1 & -0.07 \\
\hline C2 & 0.05 \\
\hline C3 & 0.17 \\
\hline C4 & 0.29 \\
\hline C5 & 0.41 \\
\hline C6 & 0.58 \\
\hline C7 & 0.75 \\
\hline C8 & 0.91 \\
\hline
\end{tabular}

32 ファン性能とモ一ダル型旋回失速の発生過程

図3に対象とした小スタッガ角での, ファン性能を示 す、縦軸と横軸はそれぞれ，動翼先端周速を基にした 圧力保数 $(\psi)$ と流量係数 $(\phi)$ を示している. 以下では流 量係数 $0.462 ， 0.440 ， 0.429 ， 0.397$ の測定点をそれぞ れ，作動点 $\mathrm{A}, \mathrm{B}, \mathrm{C}, \mathrm{D}$ と呼ぶ。

図 4 に動翼前縁部(図 1のP1)での圧力変動波形を示 す. 縦軸慚翼の先端周速を用いて無次元化した圧力 変動係数 $\left(\mathrm{Cp}^{\prime}\right)$ を，横軸烓動翼回転周期を用いて無次 元化した時間( T )を示している. 図中の圧力変動は, ローパス・フィルタを介して翼通過周波数成分（以下， BPF と略す) を除去している. 作動点 A では, 失速 セルの発生を示す変動は確認できない. 作動点 B で は，動翼回転よりも変動周期の長い微小じょう乱波が 確認できる. 作動点 C では，大スケール失速セルの 発生が確認できる. 作動点 B と C で確認できた微小 じょう乱波と大スケール失速セルは, 発生と消滅を不 規則に繰り返していた．作動点 D では大スケール失 速セルが，作動点 Cに比べて発達している.

図 5 に, $\mathrm{P} 1$ と $\mathrm{P} 2$ 間での相互相関関数の変化を示す. 縦軸は相互相関関数の值を示している. 作動点 $\mathrm{B}$ と C，およびDでの相互相関関数は，周期的な変化を示 


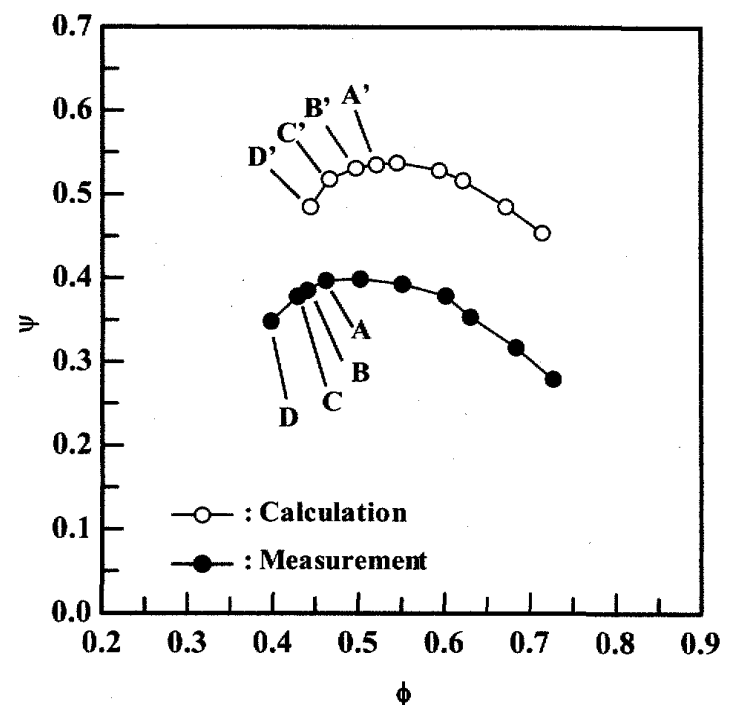

Fig. 3 Comparison of pressure-rise characteristic between measurement and calculation

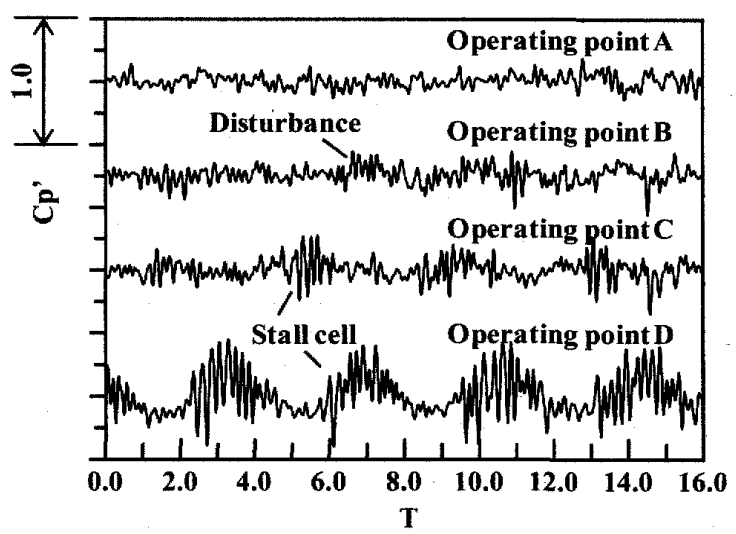

Fig. 4 Pressure fluctuations near rotor leading edge

している. 上述したように，微小じょう乱波の変動周 期は動翼の回転周期よりも長く，微小じょう乱波の個 数は 1 個と考えられる. 微小じょう乱波の個数が 1 個 と仮定した場合，作動点 B でのピーク間の時間差 (3.78)より求まる微小じょう乱波の伝播速度は，動翼 回転速度の $26 \%$ となる. 同様に, 相互相関関数のピ 一ク間の時間差より求めた作動点 $\mathrm{C}$ と D での大スケ 一ル失速セルの伝播速度はそれぞれ，動翼回転速度の $25 \%$ と $28 \%$ あるる.

Garnier ら(2)は，モーダル型の旋回失速発生過程で 観察された微小じょう乱波が, 発達した失速セルより もわずかに遅い速度で伝播することを示している．ま た，微小じょう乱波から発達した失速セルは，小スケ 一ル失速セルから発達したセルに比べて大きく，伝播 速度が遅いことが, Camp と Day(1)によって示されて いる. 上述したように, 微小じょう乱の伝播速度は, 発達した大スケール失速セルの伝播速度に比べて，わ

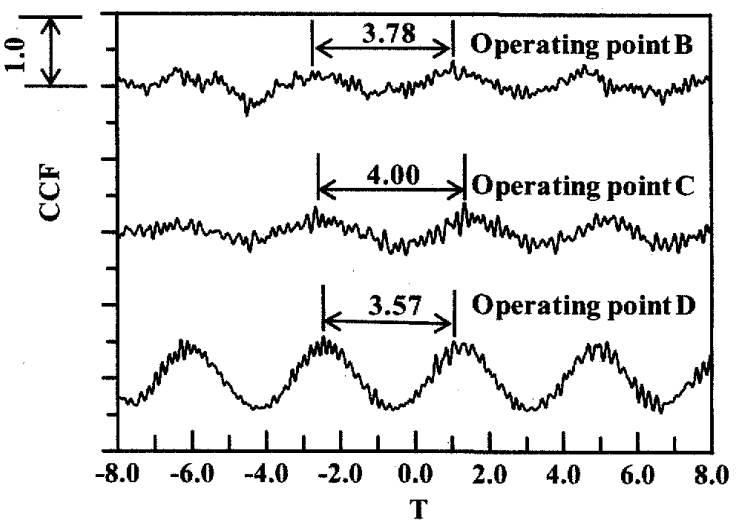

Fig. 5 Cross correlation functions of pressure fluctuations near rotor leading edge

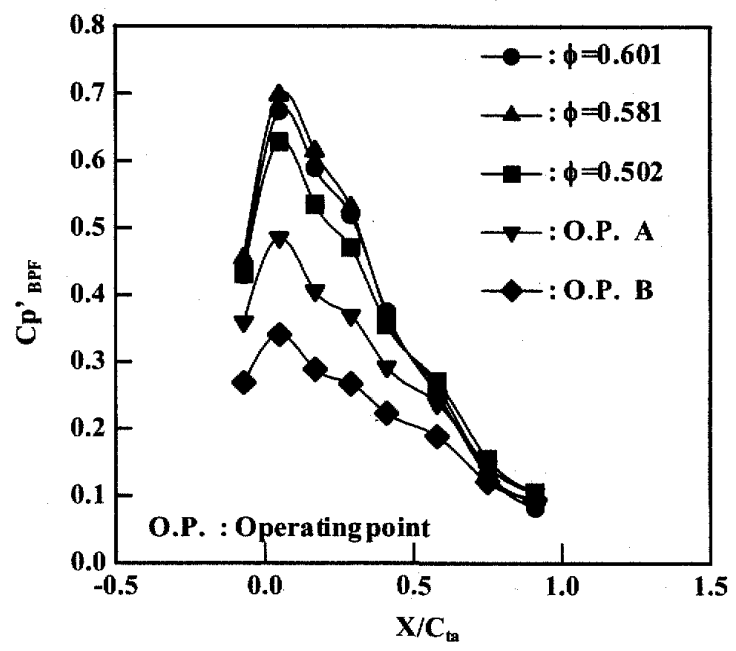

Fig. 6 Change in blade loading at tip

ずかに遅くなっていた．また，作動点 D での大スケ 一ル失速セルの伝播速度は, 前報 3 に示した小スケー ル失速セルから発達した大スケール失速セルの伝播速 度の 41\%よりも遅くなっている.これより, 小スタ ッガ角での旋回失速発生過程がモーダル型であり, 作 動点 B で確認できた微小じょう乱波がモ一ダル波で あることが分かる.

3.3 動翼先端負荷の変化 図 6 にケーシング圧力 変動の $\mathrm{BPF}$ 成分の変化を示す. $\mathrm{BPF}$ 成分の圧力変動 は, 図 2 に示した $\mathrm{C} 1$ から C8 の位置での圧力変動又 ペクトルから求めた. 横軸は軸力向コード長で無次元 化した動翼前縁からの距離 $\left(\mathrm{X} / \mathrm{C}_{\mathrm{a}}\right)$ を, 縦軸は動翼先 端周速で無次元化した BPF 成分の圧力変動(Cp'BFF)を 示している. 最大圧力変動の位置は, $\phi=0.601$ の作動 点から作動点 $\mathrm{B}$ にかけて変化しておらず, ほぼ前縁 である. $\phi=0.581$ の作動点では, $\phi=0.601$ に比べて最 大圧力変動が大きくなっている. $\phi=0.502$ の作動点で 


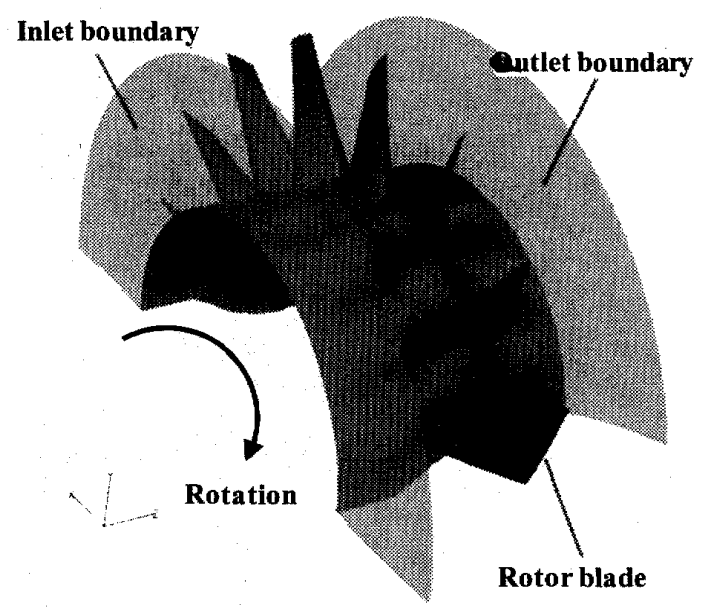

Fig. 7 Computational model for rotor blades

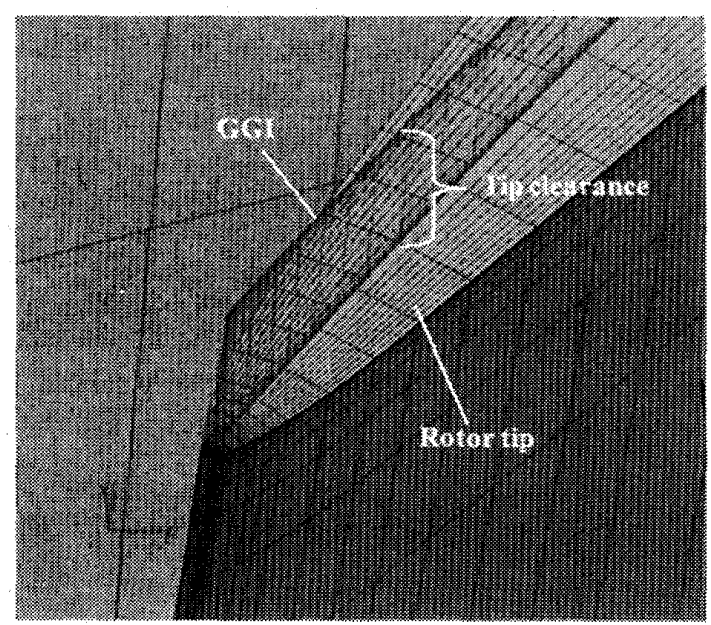

Fig. 8 Computational grid on rotor tip and in tip clearance

は最大圧力変動が低下しており, 作動点 A と B では, さらに低下している.

ケーシング圧力変動の BPF 成分は, 動翼先端での圧 力面と負圧面の圧力差に相当し，図6に示した分布は 動翼先端の翼負荷に対応している. 図3に示したファ ン性能と図 4 に示した圧力変動も併せて, 図 6 に示し た翼負荷の変化を考察すると, 動翼先端は圧力上昇が 最大となる $\phi=0.502$ からモーダル波の発生が確認でき た作動点 B にかけて 失速している. 上述した動翼先 端での負荷変化には, 翼端漏れ流れが影響を及ぼして いると考えられる.このため, 翼端瘺れ流れを含んだ 動翼先端流れ場の変化を数值解析により検討した.

\section{4. 数值解析による動瓄先端流れ場の検討}

4.1 解析モデルと数值解析方法 図 7 に解析モデ ルを示す. 事前に実施した解析モデルと解析格子，お よび乱流モデルのファン性能予測に及ぼす影響の検討
結果より，動翼半周分に相当する 8 翼間の解析が， 1 翼間の場合に比べて作動限界点付近での収束性が高く, 圧力上昇の変化も実験結果と類似していることが分か った. これは翼間流れへの周期境界の影響が小さいた めと考えられ，解析モデルとしては動翼の 8 翼間を対 象とした. 解析格子は ANSYS TurboGrid 11.0 $0^{(2)}$ を用い て作成した. 動翼 1 翼間の要素数は 645, 912 であり,

図 8 に示したように動翼の端面の要素数は 20 , 翼端 隙間内の要素数は 40 である. 解析モデル全体での要 素数は 5, 167, 296である.

解析では ANSYS CFX 11. $0^{(13)}$ を用いて, 圧縮性の定常 3 次元 RANS 解析を䒠施した. 対流項の離散化には 2 次 精度の風上スキームを適用し, 乱流モデルには標準 k- $\varepsilon$ モデルを適用した. 流入境界は動翼前縁からハブ コード長上流に設定し，流出境界は動翼偻縁からハブ コード長下流に設定した. 流入境界には全圧と全温, およひ流入角を与えた. 流入角としては，予旋回無し の条件を与えた，流出境界には，寒験で測定した質量 流量を与えた。

図 7に示した解析モデルの周方向の両端には, 周期 境界条件を設定した。翼端隙間部には図8に示したよ うに, CFX のオプションである GGI (Ceneral Grid

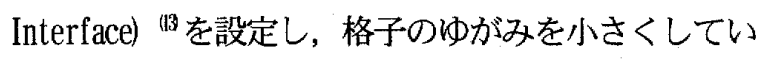
る. 設置位置は図 8 に示した翼端の厚み中央部である. GGI 上ではコントロールサーフェス法により, 不一致 の節点間の物理量を接続している. 壁面境界の条件は 壁関数を用いて設定した. 解析の時間刻みは, CFX の オプションである Auto Timescale を用いて設定した. 本解析の時間刻みは，動翼回転周期の $290 \times 10^{-2}(\mathrm{~s})$ に 対して $4.61 \times 10^{-4}(\mathrm{~s})$ となっている.

42 動瑅全压上昇と動翼先端負荷の变化 図 3 に 動翼流入境界之流出境界間で求めた全圧上昇の解析結 果を示す. 以下では, 解析結果の流量係数 0.521 , 0.497，0.466，0.444 の作動点をそれぞれ，A'， B'， C'，D' 乙呼ぶ。解析結果の全圧上昇は, 図 1 に示 した吸込ケーシングと静翼列，およびディフューザ部 での損失を含んでいないため，実験結果に比べて高く なっている. 解析結果の全圧上昇は作動点 $\mathrm{A}^{\prime}$ で最大 となっており, 作動点 B’ から D’ にかけて低下して いる. 全圧上昇が最大となる作動点は, 実駼結果に比 べてやや大流量側にずれているものの, 流量に対する 全圧上昇の変化は実験結果亡類似している.

図 9 に解析により得られた翼高さ $98 \%$ 位置 ( $\mathrm{h} / \mathrm{H}=0.98)$ での翼面圧力分布の変化を示す。縦軸は動 翼先端周速を基にした翼面圧力係数(Cp)を，横軸は動 翼先端コード長で無次元化した前縁からの距離( $\left.\mathrm{X} / \mathrm{C}_{t}\right)$ 


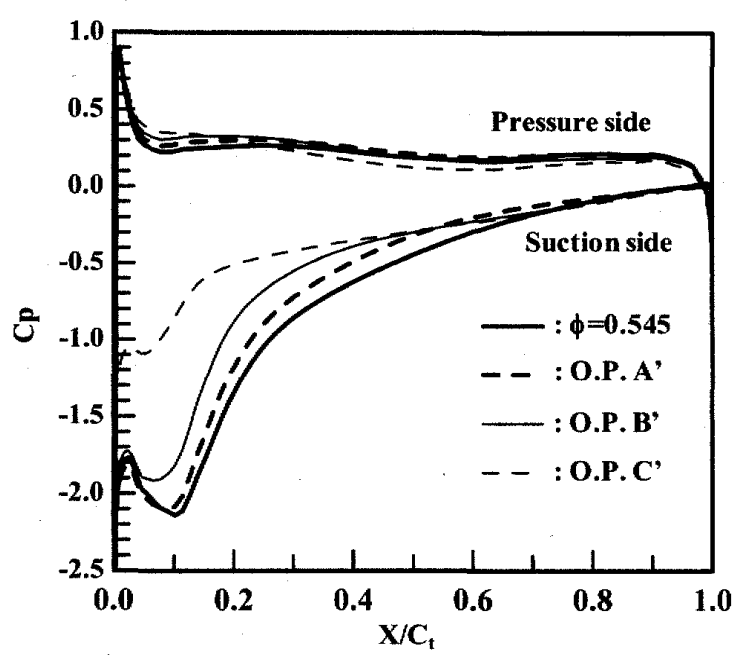

Fig. 9 Surface pressure distributions at rotor tip

を示している. 作動点 $\mathrm{A}^{\prime}$ での負圧面上の最低圧力位 置は， $\phi=0.545$ に比べて前縁側 $\mathrm{X} / \mathrm{C}=0.0)$ に移動してい る. 作動点 $\mathrm{A}^{\prime}$ での負圧面上の最低圧力は $\phi=0.545$ に 比べてわずかに高くなっており，作動点 B' から C' にかけてさらに高くなっている. 翼負荷の観点から考 察すると, 動翼先端は作動点 $\mathrm{A}^{\prime}$ 付近で負荷限界に達 しており, 作動点 B'とC'では失速している.この 傾向は, 図6に示した実験結果と一致している.

図3に示したように, 全圧上昇が最大となる作動点 は実験結果に比べて大流量側にずれているものの, 解 析での動翼全圧上昇の流量に対する変化は, 実験結果 乙類似していた. 図6の実験結果からは, $\phi=0.502$ の 作動点で動翼先端は失速しているのが分かった. 解析 結果でも, $\phi=0.497$ の作動点 B'で動翼先端は失速し ており, 実験結果と一致していた.これより, モ一ダ ル波の発生点付近での動翼先端流れ場を本解析により 再現できていると考える.

4.3 動翼先端流れ場 図 10 に $\mathrm{h} / \mathrm{H}=0.98$ での相対 速度ベクトルを示す. 作動点 A' では, 負圧面上に後 縁はく離による逆流が発生している. 動翼への流入流 れと翼端漏れ流れの境界（図中, Interface と示す）は 隣接する動翼の後縁にむかって延びている. 作動点 B' では，この後縁はく離による逆流領域が前縁側へ 拡がるとともに, 後縁から翼間に向かう逆流も発生し ている. 負圧面から流路中央にかけての動翼への流入 流れと翼端漏れ流れの境界は, 作動点 A'に比べて上 流に移動している.しかし, 隣接翼の圧力面付近の境 界は, 後縁に向加て延びている. さらに作動点 C' と D'では, 負圧面上のはく離域は動翼前縁付近まで 拡がり, 後縁からの逆流領域も動翼前縁付近まで拡が っている. これらの逆流の影響により, 負圧面から流

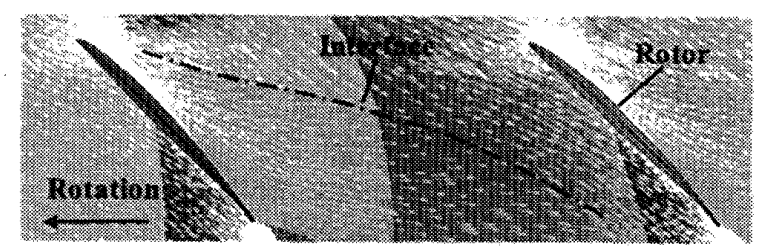

(a) Operating point $A^{\prime}$

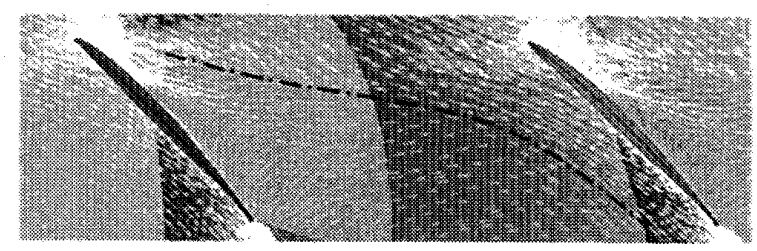

(b) Operating point B'

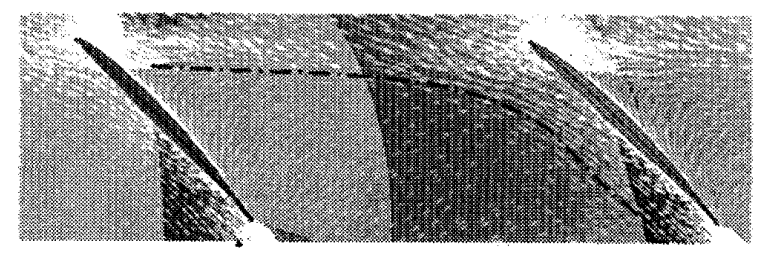

(c) Operating point $C^{\prime}$

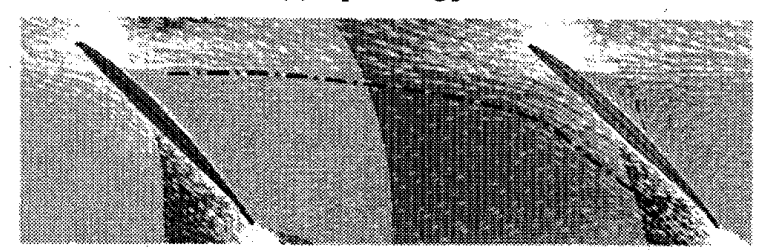

(d) Operating point $D^{\prime}$

Fig. 10 Change in relative flow vector at $h / H=0.98$

路中央にかけての動翼への流入流れと翼端漏れ流れの 境界は作動点 B’に比べて, さらに上流側に移動して おり，動翼前縁位置まで達している.しかし，作動点 C'と D'での隣接翼の圧力面付近の境界は, 作動点 B' と同様, 圧力面とほぼ平行となって後縁に向かっ て延びている.

Vo ら(6)は小スケール失速セルの発生条件を調べて おり, 第一の発生条件として流入流れ之翼端漏れ流れ の境界が動翼前縁と平行になること, 第二の発生条件 として後縁からの逆流の発生を示している. また,

Hah ら(7)は，小スケール失速七ルの発生時に翼端漏れ 流れが動翼前縁から隣接する翼間へ流入することを示 している. 前報(4)(5)に示したように，スパイク型の旋 回失速の発生過程が確認できた設計スタッガ角の条件 では, 小スケール失速セルの発生点付近で, 動翼後縁 からの逆流が発生していた. また, 流入流れと翼端漏 れ流れの境界か慟翼前縁と平行になるとともに，この 境界が隣接翼の前縁にまで達していた. さらに, 小又 ケール失速セルの発生点では, 翼端漏れ流れが隣接す る翼間に前縁から流入していた。

図 10 に示した小スタッガ角の条件でも，動翼先端 が失速した作動点 B'で, 後縁からの逆流が発生して 


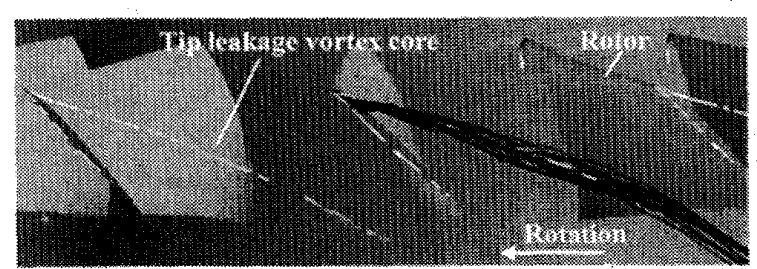

(a) Operating point $\mathbf{A}^{\prime}$

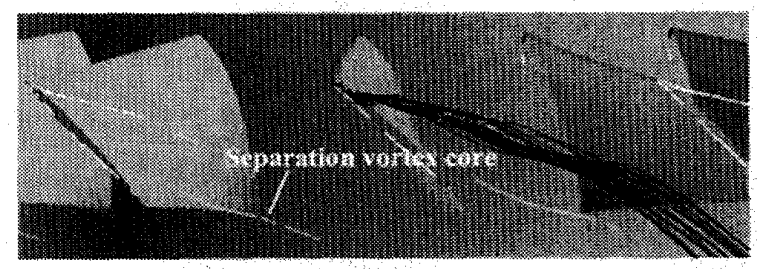

(b) Operating point B'

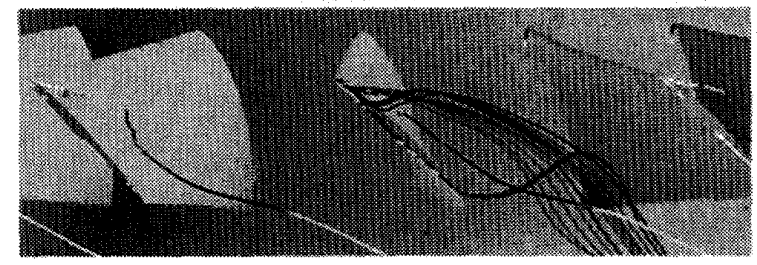

(c) Operating point $C^{\prime}$

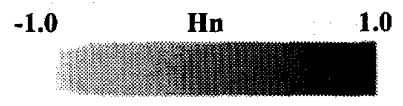

Fig. 11 Change in vortex core at tip

いた. また，動翼負圧面から翼間中央にかけての流入 流れ之翼端漏れ流れの境界は, 動翼前粶之平行となつ ていた. しかし，さらに動翼先端の負荷が低下した作 動点 $\mathrm{C}^{\prime}$. でも, 隣接翼の圧力面付近の境界は動翼後縁 に向かって延びており，隣接翼の前縁には達していな い.このため, 翼端漏れ流れは隣接する翼間への流入 しておらず, 小スタッガ角のモーダル波の発生点付近 での動翼先端流れ場は，スパイク型の発生条件と異な つている.

4.4 嫼端扁れ渦 図 11 に翼端漏れ渦の変化を示 す，翼端漏れ渦は FIELDVIEW(14)を用いて同定した渦 コアと, 動翼前縁の翼端上からの流線で可視化した. 渦コアは無次元へリシティで色づけしている. 流線は 黒線で示している. 作動点A'とB'では渦コアで同 定された翼端漏れ渦が，動翼前縁から動翼出口に向か つて延びている. 翼端漏れ渦に沿った無次元へリシテ イは，ほぼー1の值となっている，流線は翼端漏れ渦 の周囲に螺旋状に巻きついている. 作動点 B’では, 負圧面付近に翼端漏れ渦とは異なった渦コアか確認で きる. 図 10 に示した先端流れ場と合わせて考察する と, この佩コアは後縁でのはく離渦を同定している. このはく離渦に沿った無次元へリシティもー1の值と なっている. 作動点 C'での翼端漏れ渦は, 動翼前縁
付近で途切れている. 動翼前縁付近の流線は, 漏れ渦 の周囲に巻きついているものの，翼間では螺抒状に巻 き上がっていない，翼端漏れ渦に沿った無次元へリシ ティはー1の値のままである. 作動点 C' でのはく離 渦は作動点 B'に比べて明確に確認でき，はく離渦が 発達していると考える. はく離瀜にそった無次元へリ シティは翼間では1の值となっているが, 動翼出口で - 1 まで変化している.

古川ら(8),(9)は，翼端漏れ渦の崩壊時に，翼端漏れ渦 に沿った無次元へリシティの值が 1 から 0へ急変する とともに, 渦コアまわりの流線か膨らむことを示して いる. また，渦コアが翼間内で屈曲することも示して いる. 前報(5)に示したようにスパイク型の旋回失速の 発生過程が確認できた設計スタッガ角の条件では，小 スケール失速セルの発生点付近で, 翼端漏れ渦周りの 流線か瀷間で膨らんでいた. また，翼端漏れ渦は翼間 内で隣接翼の圧力面に向かって屈曲しており, 翼端漏 れ渦が崩填していることが確認できた。

図 11 に示した小スタッガ角の条件では, 翼端漏れ 渦周りの流線は膨らんではいない。 また, 翼端漏れ渦 は, 隣接翼の圧力面に向かって屈曲していない.さら に，翼端漏れ渦に沿った無次元へリシティはー1の值 を保っている. 古川ら(8),(9)と前報(5)に示したスパイク 型の発生過程での翼端漏れ渦の変化を参考にすると, 小スタッガ角のモーダル波の発生点付近では, 翼端漏 れ渦の崩壊は発生しない。

4.5 動罢負圧面上のはく離流れ 図 12 に負圧面上 での限界流線の変化を, 渦コアで同定した翼端漏孔渦 とはく離渦とともに示す. 限界流線も渦コアと同様, FIELDVIEW(14)を用いて可視化した. 作動点 A'での 後縁付近の限界流線は動翼先端方向を向いており, 動 翼先端へ向かう2 次流れが発生している. 作動点 B' では, 動翼先端部の後緑付近の限界流線が前縁方向に 向かっており，2 次流れが強くなり動翼後縁で逆流が 発生している. また, 先端直下の前縁付近に, 2 次流 れにより誘起された渦状のはく離点が確認できる. 図 11 と図 12 で確認できるはく離渦は，この洞状のはく 離点を起点とした 3 次元瀜であると考える. 作動点 C' では, 渦状のはく離点が前縁から翼中央部に移動 している. また，このはく離点から延びる3次元はく 離渦が明確に確認できる.

前報(5)で示したスパイク型の発生過程では, 翼端漏 れ渦の崩壊により, 動翼後縁付近の負圧面上から伸び る3次元はく離渦が発達していた. 小スケール失速セ ルの発生点近傍での 3 次元はく離渦の発達は, 山田ら (10)よっても確認されており, 翼端漏れ渦の崩壊によ 


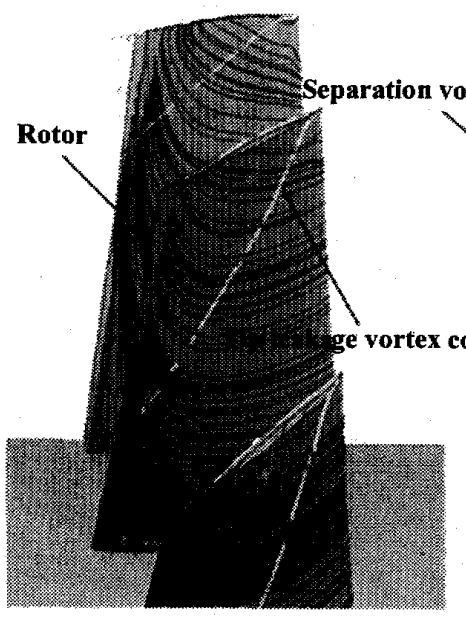

(a) Operating point $A^{\prime}$

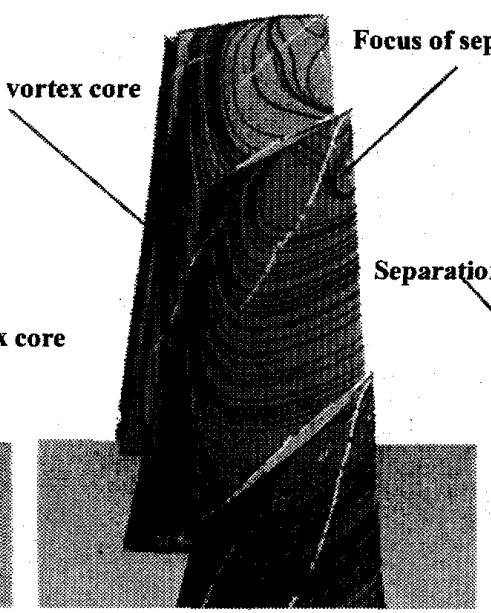

(b) Operating point B'

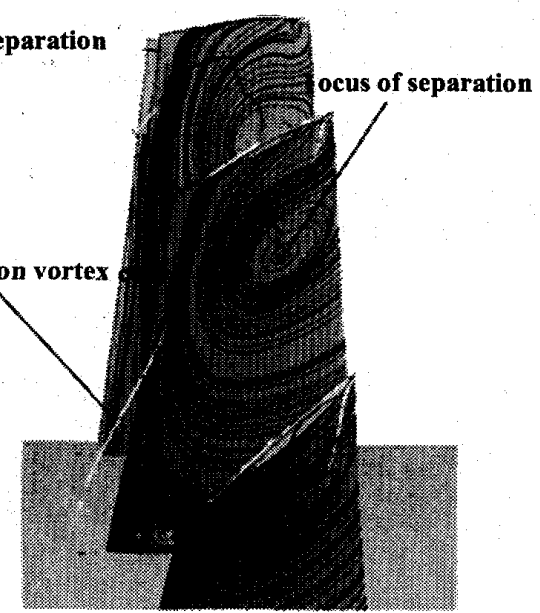

(c) Operating point C'

Fig. 12 Change in limiting streamline on blade suction surface and separation vortex core

り誘起された 3 次元はく離渦が小スケール失速セルの 発生に影響を及ぼしていることが示唆された。

前節に示したように, 小スタッガ角の条件では翼端 漏れ渦の崩壊は確認できなかった. しかし, 図 12 に 示したように，動翼先端が失速した作動点 B' から C'にかけて, 負圧面上の 2 次流れから 3 次元はく離 渦が誘起され，発達している. 定常解析であるため, この3次元はく離渦の非定常挙動は不明であるが，負 圧面上の 2 次流れから誘起された 3 次元はく離渦が, モーダル波の発生に影響を及ぼしていることが示唆さ れる.

\section{5. 結 論}

モーダル型の旋回失速発生メカニズムの解明を目的 として，モーダル波の発生点近傍での動翼先端流れ場 之翼端漏れ渦の変化を数值解析により調べ, 以下の結 論を得た。

(1) モ一ダル波の発生点付近では，スパイク型の発生 過程と同様, 動翼後椂からの逆流が発生している. しかし, スパイク型の発生過程とは異なり, 動翼 流入流れと翼端漏れ流れの境界は隣接翼の前縁ま で延びず，隣接する翼間への翼端漏れ流れの流入 は発生しない.

(2) モーダル型の発生過程では, 動翼翼端漏れ渦の崩 壊は発生しない。

(3) モ一ダル型の発生過程では, 動翼負圧面上の 2 次 流れにより誘起された 3 次元はく離渦が発達する.

（4）以上の結論より，動翼負圧面上の 2 次流れにより 誘起された 3 次元はく離渦が, モーダル波の発生 に影響を及ぼしていることが示唆された.

\section{参考文献}

(1) Camp, T. R. and Day, I. J., A study of Spike and Modal Phenomena in a Low-Speed Axial Compressor, Transaction of the ASME, Journal of Turbomachinery Vol. 120 (1998), pp. 393-401.

(2) Garnier, V. H., Epstein, A H., and Greitzer, E. M., Rotating Wave as a Stall Inception Indication in Axial Compressors, Transaction of the ASME, Journal of Turbomachinery Vol. 113(1991), pp. 290-301.

(3) Nishioka, T., Kuroda, S., and Kozu, T., Spike and Modal Stall-Inception Patterns in a VariablePitch Axial-Flow Fan, Transactions of the Japan Society of Mechanical Engineers, Series B, Vol. 70, No. 695 (2004) , pp. 96-103.

(4) Nishioka, T., Kanno, T., and Hayami, H., Effect of Rotor Tip Leakage Flow on Spike-Type Stall Inception, Transactions of the Japan Society of Mechanical Engineers, Series B, Vol. 73, No. 732 (2007) ,pp. 71-178.

(5) Nishioka, T., Kanno, T., and Hayami, H., Rotor Tip Flow-Field near Inception Point of Short Length-Scale Stall Cell in an Axial-Flow Fan, Transactions of the Japan Saciety of Mechanical Engineers, Series B, Vol. 75, No. 753 (2009), pp. 219-227.

(6) Vo, H. D., Tan, C. S., and Greitzer, E. M., Criteria for Spike Initiated Rotating Stall, Proceedings of ASME Turbo Expo 2005 (2005), GT2005-68374..

(7) Hah, C., Bergner, J., and Schiffer, H., Short 
Length-Scale Rotating Stall Inception in a Transonic Axial Compressor - Criteria and Mechanisms, Proceedings of ASME Turbo Expo 2006 (2006), GT2006-90045.

(8) Furukawa, M., Inoue, M., Saiki, K., and Yamada, $\mathrm{K}$, The Role of Tip Leakage Vortex Breakdown in Compressor Rotor Aerodynamics, Transaction of the ASME, Journal of Turbomachinery Vol. 121, No. 3 (1999), pp. 469-480.

(9) Furukawa, M., Saiki, K, Yamada, K, and Inoue, M., Anomalous Flow Phenomena Due to Breakdown of Tip leakage Vortex in an Axial Compressor rotor at Near-Stall Condition, Transactions of the Japan Society of Mechanical Engineers, Series B, Vol. 66, No. 644 (2000), pp. 83-91.
(10) Yamada, K, Furukawa, M., and Inoue, M., Unsteady Three-Dimensional Vortical Flow Structure in an Axial Compressor Rotor at Rotating Stall Inception, Proceedings of 79th Fluid Engineering Conference of the Japan Society of Mechanical Engineers (2001), 1018.

(11) Simpson, A. K. and Longley, J., An Experimental Study of The Inception of Rotating Stall in a Single-Stage Low-Speed Axial Compressor, Proceedings of ASME Turbo Expo 2007 (2007), GT2007-27181.

(12) ANSYS, TurboGrid 11.0 Reference Guide (2007).

(13) ANSYS, CFX 11.0 Reference Guide (2007).

(14) Intelligent Light, FIELDVIEW Reference Guide (2006). 